\title{
Diets of leaf litter-associated invertebrates in three tropical streams
}

\author{
Ana M. Chará-Serna ${ }^{1,2 *}$, Julián D. Chará ${ }^{1,3}$, María del Carmen Zúñiga ${ }^{1,2}$, \\ Richard G. Pearson ${ }^{4}$ and Luz Boyero ${ }^{4,5}$ \\ ${ }^{1}$ Centro para la Investigación en Sistemas Sostenibles de Producción Agropecuaria, CIPAV, Carrera 25 No. 6-62, Cali, Colombia \\ 2 Departamento de Biología, Grupo de Investigaciones Entomológicas, Universidad del Valle, Apartado Aéreo 25360, Cali, Colombia \\ 3 Centro de Investigaciones y Estudios en Biodiversidad y Recursos Genéticos, CIEBREG, P.O.B. 97, Pereira, Colombia \\ ${ }^{4}$ School of Marine and Tropical Biology, James Cook University, Townsville, QLD 4811, Australia \\ 5 Wetland Ecology Department, Doñana Biological Station-CSIC, Avda Americo Vespucio s/n, 41092 Sevilla, Spain
}

Received 20 May 2011; Accepted 27 October 2011

\begin{abstract}
Shredders play a major ecological role in temperate streams, but their numerical importance is highly variable within the tropics. Detailed studies on the diets of tropical stream invertebrates are advisable to be able to better describe and understand this variation. Here, we examined the diets of invertebrates collected from the leaf litter of three tropical streams in Colombia, using gut content analysis. Fine and coarse particulate organic matter were the main food resources for invertebrates, which could be divided into four main dietary groups: predators, shredders, specialist collectors and generalist collectors. While the specialist collectors were the most numerically abundant group (54\%), shredder biomass accounted for $63 \%$ of total invertebrate biomass, suggesting that shredders play a significant ecological role in the study streams. We describe the diets of 12 out of 47 taxa that were previously unknown, which indicates that knowledge about the feeding ecology of tropical stream invertebrates is still incipient.
\end{abstract}

Key words: Aquatic invertebrates / gut contents / shredders / dietary groups / trophic guilds

\section{Introduction}

Invertebrate shredders play a major role in the biological decomposition of leaf material in temperate streams (Webster and Benfield, 1986; Allan, 1995; Boyero et al. 2011a). Their feeding activities produce large amounts of fine particulate organic matter (FPOM; Cummins, 1974), which is used by other detritivore guilds (Heard and Richardson, 1995), and they incorporate allochthonous carbon and nutrients into animal biomass (Chung and Suberkropp, 2009), thus making it available for higher trophic levels (Wallace et al., 1997).

The importance of shredders in tropical streams, however, is not so clear. Several studies have suggested that tropical shredders are scarce (Dobson et al., 2002; Rueda-Delgado et al., 2006; Wantzen and Wagner, 2006; Gonçalves et al., 2007), while others have shown the opposite (Cheshire et al., 2005; Wright and Covich, 2005; Chará et al., 2007; Camacho et al., 2009; Ríos-Touma et al., 2009; Yule et al., 2009). A recent global study has

\footnotetext{
*Corresponding author: ana@cipav.org.co
}

demonstrated not only that shredder diversity increases with latitude (Boyero et al., 2011b) but also that variability in shredder abundance and diversity within the tropics is higher than within temperate areas (Boyero et al., 2011c).

Information on tropical stream food webs and the feeding ecology of tropical stream invertebrates is still incipient (Boyero et al., 2009), except for a few locations such as Hong Kong (Mantel et al., 2004) and north Queensland (Cheshire et al., 2005). Some information also exists for Kenya (Dobson et al., 2002), Brazil (Motta and Uieda, 2004), Bolivia (Tomanova et al., 2006) and Indonesia (Yule et al., 2010). There is evidence that related species occurring in different regions often have different diets (Cheshire et al., 2005; Tomanova et al., 2006), so detailed studies on tropical stream invertebrate diets are advisable. Here, we describe the diets of multiple invertebrate species from three Colombian streams through gut content analysis. We predict that classification of invertebrates into trophic guilds based on their diets will provide evidence of the important ecological role of shredders in these tropical streams. 
Table 1. Physical and chemical parameters recorded in the study sites.

\begin{tabular}{|c|c|c|c|}
\hline & Paloblanco & La Hacienda & Marianela \\
\hline Altitude (m asl) & 1792 & 1858 & 1911 \\
\hline Mean width (m) & 2.4 & 2.4 & 3.8 \\
\hline Mean depth (cm) & 16.5 & 9.3 & 18 \\
\hline$\%$ Canopy cover & 60 & 70 & 50 \\
\hline$\%$ Pool habitats & 42 & 57 & 67 \\
\hline$\%$ Riffle habitats & 58 & 43 & 33 \\
\hline$\%$ Leaf litter in pools & 33 & 50 & 40 \\
\hline$\%$ Leaf litter in riffles & 54 & 54 & 25 \\
\hline \multicolumn{4}{|l|}{ Substrate composition: } \\
\hline$\%$ Boulder $(>256 \mathrm{~mm})$ & 0 & 15 & 60 \\
\hline$\%$ Cobble $(64-256 \mathrm{~mm})$ & 15 & 60 & 0 \\
\hline$\%$ Pebble $(16-64 \mathrm{~mm})$ & 80 & 15 & 20 \\
\hline$\%$ Gravel $(2-16 \mathrm{~mm})$ & 0 & 10 & 20 \\
\hline$\%$ Sand $(<2 \mathrm{~mm})$ & 5 & 0 & 0 \\
\hline Water temperature $\left({ }^{\circ} \mathrm{C}\right)$ & 15.5 & 14.9 & 14.3 \\
\hline Conductivity $\left(\mu \mathrm{S} . \mathrm{cm}^{-1}\right)$ & 48 & 41 & 35 \\
\hline $\mathrm{pH}$ & 7.1 & 7.3 & 7.5 \\
\hline Alkalinity $\left(\mathrm{mg} \mathrm{CaCO} 3 \cdot \mathrm{L}^{-1}\right)$ & 24.9 & 21.3 & 17.9 \\
\hline Total phosphorus $\left(\mu \mathrm{g} \mathrm{P}^{-} \mathrm{PO}_{4} \cdot \mathrm{L}^{-1}\right)$ & 70 & 60 & 40 \\
\hline Total nitrogen (mg N.L $\left.{ }^{-1}\right)$ & $<1.6$ & $<1.6$ & $<1.6$ \\
\hline Nitrites $\left(\mathrm{mg} \mathrm{N}-\mathrm{NO}_{2} \cdot \mathrm{L}^{-1}\right)$ & $<0.01$ & $<0.01$ & $<0.01$ \\
\hline Nitrates $\left(\mathrm{mg} \mathrm{N}-\mathrm{NO}_{3} \cdot \mathrm{L}^{-1}\right)$ & & 0.7 & 0.7 \\
\hline
\end{tabular}

\section{Materials and methods}

The study sites were Paloblanco $\left(4^{\circ} 43^{\prime} 45^{\prime \prime} \mathrm{N}\right.$,

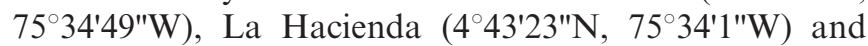
Marianela $\left(4^{\circ} 44^{\prime} 19^{\prime \prime} \mathrm{N}, 75^{\circ} 33^{\prime} 19^{\prime \prime} \mathrm{W}\right)$, three first-order forest streams located in the middle watershed of the Otún River (Central Andes of Colombia), between 1792 and $1911 \mathrm{~m}$ above sea level. Physical and chemical characteristics of the streams were recorded in a single measurement and summarized in Table 1. Five riffles and five pools were sampled in each stream during the dry season (February) of 2007; ten replicate leaf-litter samples were taken from leaf packs, by extracting litter from within a $20 \times 20 \mathrm{~cm}$ frame with a dip net $(0.5 \mathrm{~mm}$ mesh $)$ placed immediately downstream.

Invertebrates were sorted from the leaf litter in the field, preserved in $85 \%$ ethanol and transported to the laboratory, where they were identified to the lowest possible taxonomic level (generally genus). Excess moisture was removed from the invertebrates with tissue paper, and individuals from each taxon were separately weighed to obtain a relative measure of biomass. Leaves were oven dried at $60^{\circ} \mathrm{C}$ for 5 days and weighed.

In order to assign the collected invertebrates to trophic guilds, the gut contents of 1-15 individuals of each taxon were examined following the methods proposed by Cheshire et al. (2005) and Tomanova et al. (2006). Guts were removed and mounted in glycerin to create semipermanent slides, which were examined under a microscope (up to $100 \times$ magnification). The proportion of each food item was estimated from the relative area of food particles in 20 randomly chosen fields on each slide.
Gut contents were divided into six categories: (1) FPOM, (2) coarse particulate organic matter (CPOM), (3) algae (ALG), (4) animal tissue (AT), (5) mineral material (MM), and (6) fungi (FUNG).

Principal components analysis (PCA) was used to describe variation in invertebrate assemblages based on their diets, using the average percentage of each food item in the guts of individuals (arcsin-square-root transformed). We further used cluster analysis (Euclidean distance and Ward's clustering method) to classify invertebrate taxa into groups with similar gut contents. Only taxa with at least three individuals examined were included in these analyses (individuals from different streams and habitats were pooled to have a sufficient number of individuals). Both analyses and graphical presentation were performed using SPSS 12.0 for Windows and XLSTAT.

\section{Results}

\section{Sample composition}

A total of 2300 invertebrates from 71 taxa were collected, including 56 genera, 33 families, 13 orders and 3 classes. Insecta was the most important class, comprising $98 \%$ of the collected organisms. Average invertebrate abundance ranged from $2.4( \pm 2.1 \mathrm{SD})$ to $5.5( \pm 6.1 \mathrm{SD})$ individuals per gram of leaf litter, at La Hacienda and Marianela streams, respectively. Invertebrate biomass varied between $17.2( \pm 10.9 \mathrm{SD})$ and $22.4( \pm 29.1 \mathrm{SD})$ $\mathrm{mg}$ of invertebrate wet mass per gram of leaf litter dry mass, at Paloblanco and Marianela streams, respectively. 


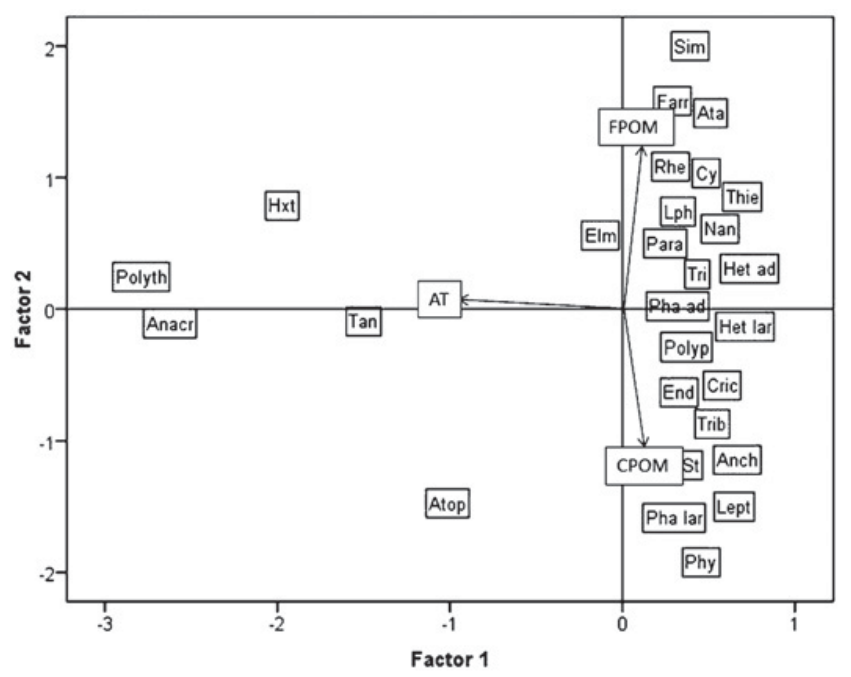

Fig. 1. Principal components analysis (PCA) of the diet composition of 26 invertebrate taxa from three Colombian streams. Factors 1 and 2 explain 53 and $38 \%$ of the variance, respectively. FPOM, fine detritus; CPOM, coarse detritus; AT, animal tissue. For abbreviations of taxa see Table 2.

\section{Gut contents analysis}

PCA and cluster analysis were performed on 26 taxa for which we had data for three or more individuals. However, we present the results for all 47 taxa with gut contents, as it may be useful information for future studies in the region (Appendix 1 available online). FPOM was the only food item found in high proportion in all individuals. The second most ingested food type was CPOM. The PCA identified two principal factors: F1, mainly determined by AT, which decreased along the axis; and F2, mainly determined by CPOM and FPOM, with CPOM decreasing and FPOM increasing along the axis. F1 and F2 explained 53 and $38 \%$ of the data variation, respectively (Fig. 1).

Four dietary groups (I-IV) were identified with the cluster analysis (Fig. 2). Mean percentages of food types in each group are presented in Figure 3. Group I contained four taxa with an average of $51 \%$ of AT in their guts, and was therefore called "predators". FPOM and CPOM were also important food resources in this group; taxa in this category included Polythoridae and Tanypodinae. Group II included nine taxa with an average of $52 \%$ of CPOM in their gut content, and were denominated "shredders". Taxa like Phylloicus, Leptonema and Anchytarsus where classified in this category. Groups III and IV were closely related and contained taxa with high proportions of FPOM. Group III contained four taxa with very high percentages of FPOM (82\%) and lower proportions of other food resources; they were called "specialist collectors". Some of the most representative taxa grouped in this category were Farrodes and Simulium. Group IV contained 11 taxa with an average of $70 \%$ of FPOM, and considerable amounts of CPOM and ALG; thus it was named "generalist collectors" and included Leptohyphes, Parametriocnemus and Heterelmis.
Relative importance of the dietary groups in the leaf-litter-associated community

The most abundant dietary group in the community was the specialist collectors, with $54 \%$ of the collected individuals. They were followed by the generalist collectors and the shredders, which accounted for 18 and $17 \%$ of the individuals, respectively. In terms of biomass, however, the relative importance of the trophic groups changed substantially. Shredders were the dominant dietary group, representing $63 \%$ of total biomass. The second most important dietary group was the predators, which comprised $17 \%$ of total biomass, even though they represented only $4 \%$ of individuals. Specialist and generalist collectors were the groups with less biomass with 7 and $3 \%$, respectively. Taxa that were not considered in the statistical analyses due to low number of individuals or empty guts comprised $6 \%$ of the abundance and $10 \%$ of total biomass.

\section{Discussion}

This is the first study addressing the trophic structure of invertebrate communities associated with submerged leaf litter in Colombian streams, and one of the few that have described the diets of tropical stream invertebrates based on gut content analysis. Such studies are crucial, as previous records suggest that genera previously allocated into a given FFG in the temperate region can exhibit different feeding habits in the tropics (e.g. Dobson et al., 2002). Although we did not attempt to classify invertebrates into FFGs, as we did not examine mouth parts, we were able to identify differences in the diets of leaf litterassociated invertebrates, compared to those previously reported by Merritt and Cummins (1996) for North American insects. For example, $60 \%$ of the gut contents of Leptonema, previously described as a collector and filterer, were composed of CPOM; Atopsyche, previously described as a predator, had some AT in their guts but presented high percentages of CPOM; and Tribelos, described as a collector in the temperate region, showed evidence of shredding activity (Table 2).

FPOM was the most important food resource for the leaf litter-associated community, as it was found in substantial proportions in the guts of all individuals. This is in agreement with results of Palmer et al. (1993) and Tomanova et al. (2006), and studies reviewed by these authors. FPOM is primarily generated from the decomposition of CPOM by shredders, micro-organisms and physical abrasion (Allan, 1995). FPOM constitutes a mostly continuous resource in the streams, and its ubiquity in the guts of leaf litter-associated invertebrates may be explained by its high availability in the habitat.

CPOM was the second most important food resource for the leaf litter invertebrate assemblage, being present in high percentages in 18 taxa. This fact, and the relative importance of shredders in terms of biomass $(63 \%)$ in leaf 


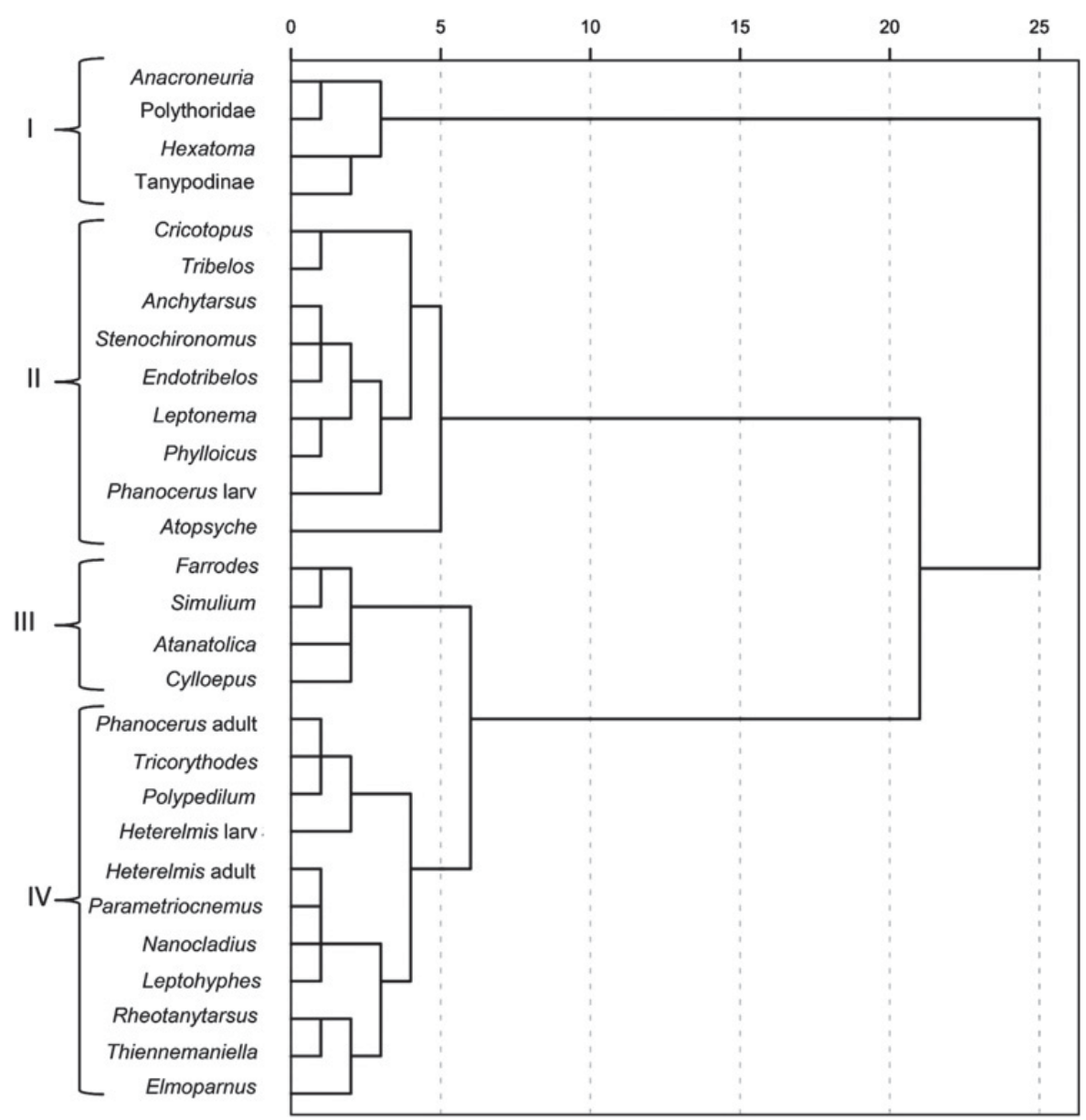

Fig. 2. Cluster analysis of 26 invertebrate taxa associated with leaf-litter packs in three Colombian streams, based on proportions of different food types in their guts. Four groups were identified: I, Predators; II, Shredders; III, Specialist collectors; IV, Generalist collectors.

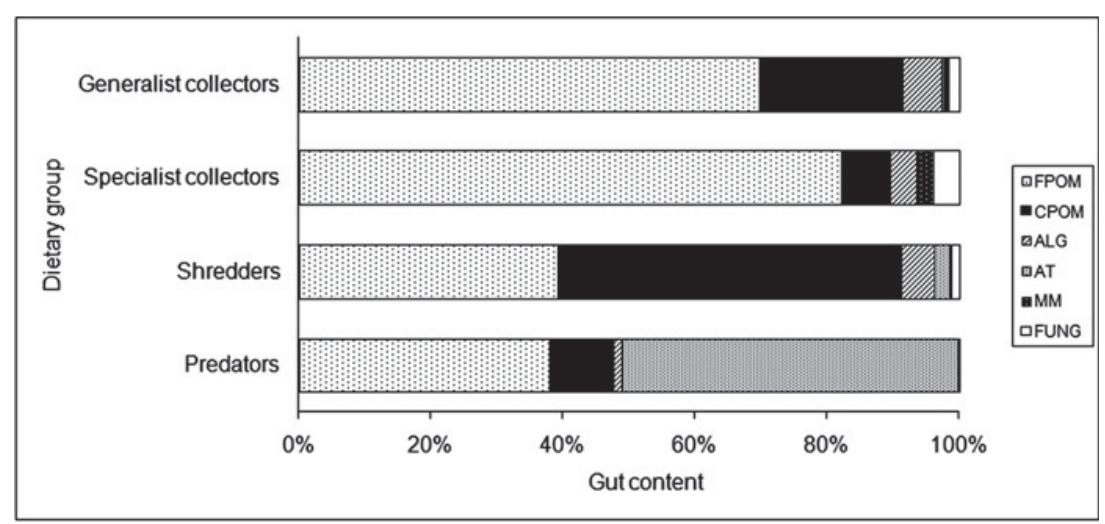

Fig. 3. Mean percentages of the different food types ingested by each dietary group found in leaf-litter packs in three Colombian streams. Dietary groups derived from cluster analysis. FPOM, fine detritus; CPOM, coarse detritus; ALG, algae; AT, animal tissue; MM, mineral material; FUNG, fungi.

litter packs, indicates that invertebrates are playing an important role in leaf litter processing in these tropical streams. This is in agreement with previous studies: Cheshire et al. (2005) found that shredders represented
$20 \%$ of the species richness and $24 \%$ of the biomass (up to $40 \%$ in pools) of invertebrate assemblages (all microhabitats included) in Australian tropical streams; Chará et al. (2007), who classified FFGs based on the literature, 
Table 2. Dietary groups identified in the present study, compared to previous reports in the literature.

\begin{tabular}{|c|c|c|c|}
\hline Taxa & Abbreviation & Dietary group present study & FFG reported in literature \\
\hline Anacroneuria & Anacr & Predators & - \\
\hline Anchytarsus & Anch & Shredders & Shredders ${ }^{1}$ \\
\hline Atanatolica & Ata & Specialist collectors & - \\
\hline Atopsyche & Atop & Shredders & Predators ${ }^{1}$ \\
\hline Cricotopus & Cric & Shredders & Shredders ${ }^{1}$ \\
\hline Cylloepus & $\mathrm{Cy}$ & Specialist collectors & - \\
\hline Elmoparnus adult & Elm & Generalist collectors & - \\
\hline Endotribelos & End & Shredders & - \\
\hline Farrodes & Farr & Specialist collectors & - \\
\hline Heterelmis larvae & Het lar & Generalist collectors & Shredders, collectors ${ }^{2}$ \\
\hline Heterelmis adult & Het ad & Generalist collectors & - \\
\hline Hexatoma & $\mathrm{Hxt}$ & Predators & Predators ${ }^{1,2}$ \\
\hline Leptohyphes & Lph & Generalist collectors & - \\
\hline Leptonema & Lept & Shredders & Collectors-filterers ${ }^{1,2}$ \\
\hline Nanocladius & Nan & Generalist collectors & Collectors ${ }^{1}$ \\
\hline Parametriocnemus & Para & Generalist collectors & Collectors $^{1}$ \\
\hline Phanocerus adult & Pha ad & Generalist collectors & Shredders, collector-scrapers ${ }^{2}$ \\
\hline Phanocerus larvae & Pha lar & Shredders & - \\
\hline Phylloicus & Phy & Shredders & Shredders-detritivores ${ }^{1}$ \\
\hline Polypedilum & Polyp & Generalist collectors & Collectors, predators ${ }^{1}$ \\
\hline Polythoridae & Polyth & Predators & - \\
\hline Rheotanytarsus & Rhe & Generalist collectors & Collectors $^{1}$ \\
\hline Simulium & Sim & Specialist collectors & Collectors ${ }^{1,3}$ \\
\hline Stenochironomus & St & Shredders & Shredders, collectors ${ }^{1}$ \\
\hline Tanypodinae & Tan & Predators & - \\
\hline Thiennemaniella & Thie & Specialist collectors & - \\
\hline Tribelos & Trib & Shredders & Collectors $^{1}$ \\
\hline Tricorythodes & Tri & Generalist collectors & Collectors $^{1}$ \\
\hline
\end{tabular}

${ }^{1}$ Merritt and Cummins (1996), ${ }^{2}$ Tomanova et al. (2006), ${ }^{3}$ Cheshire et al. (2005). Major contrasts are highlighted in boldface.

found that shredders represented $13 \%$ of the abundance and $68 \%$ of the biomass of invertebrates colonizing leaf litter bags in Andean Colombian streams; and Yule et al. (2009) found that shredders were $25 \%$ of the abundance and $82 \%$ of the biomass of benthic macroinvertebrates in Malaysian streams. However, these results contrast with those of Dobson et al. (2002), Rueda-Delgado et al. (2006) and Wantzen and Wagner (2006), who reported low numbers of shredders in several tropical streams. A more recent global study has explored variation in shredder abundance and diversity in $\sim 150$ streams from 14 regions across a latitudinal gradient, showing that shredder numbers are indeed quite variable within the tropics, but generally less important than in temperate streams (Boyero et al. 2011a, 2011b, 2011c). Although the reasons for this variation are largely unknown, water temperature and leaf litter characteristics are likely to be important (Boyero et al., 2011c).

Our study highlights the importance of considering biomass in future studies of the ecological role of different FFGs in stream food webs. We found that most collectors (e.g. Simulium, Farrodes and several genera of Chironomidae) were small-sized and abundant, while shredders (e.g. Phylloicus, Leptonema and Anchytarsus) and predators (e.g. Polythoridae and Anacroneuria) were generally larger and less numerous taxa. Our study also provides new information on the diets of 12 invertebrate Neotropical taxa. This kind of research is necessary to avoid misclassification of species into FFGs and to allow a proper description of tropical stream food webs. We provided information only for invertebrates associated with leaf litter, as our main interest was to identify shredder species and to assess their ecological importance. Future studies should describe the diets of invertebrates found in other types of microhabitat and potential diet shifts during larval development (Basaguren et al., 2002). The examination of mouthpart morphology is also desirable to classify species into FFGs and describe food webs. Our results, while limited in scope, demonstrate that shredders are an important component of leaf litter invertebrate assemblages in highland Colombian streams.

Acknowledgements. We thank Rodulfo Ospina (Universidad Nacional, Colombia) for his help in confirming Chironomidae identification, Zoraida Calle for her valuable comments on the manuscript, the Laboratorio de Investigaciones Entomológicas (Universidad del Valle) for the logistic support, the Santuario de Fauna y Flora Otún Quimbaya and the Parque Natural Regional Ucumari for providing access to the streams. Funds for this study were provided by COLCIENCIAS (contract 433-2004 with CIEBREG), SENA-COLCIENCIAS (contract 4802008 with CIPAV), the International Foundation for Science (IFS) and a Grant from the Committee for Research and Exploration of the National Geographic Society to L.B. (grant number 7980-06). 


\section{References}

Allan J.D., 1995. Stream Ecology: Structure and Function of Running Waters, Kluwer Academic Publishers, Dordrecht.

Basaguren A., Riaño P. and Pozo J., 2002. Life history patterns and dietary changes of several caddisfly (Trichoptera) species in a nortern Spain stream. Arch. Hydrobiol., 155, 23-41.

Boyero L., Ramirez A., Dudgeon D. and Pearson R.G., 2009. Are tropical streams really different? J. North Am. Benth. Soc., 28, 397-403.

Boyero L., Pearson R.G., Dudgeon D., Graça M.A.S., Gessner M.O., Albariño R.J., Ferreira V., Yule C.M., Boulton A.J., Arunachalam M., Callisto M., Chauvet E., Ramírez A., Chará J., Moretti M.S., Gonçalves J.F. Jr., Helson J.E., Chará-Serna A.M., Encalada A.C., Davies J.N., Lamothe S., Cornejo A., Castela J., Li A.O.Y., Buria L.M., Villanueva V.D., Zúñiga M.C. and Pringle C.M., 2011a. Global distribution of a key trophic guild contrasts with common latitudinal diversity patterns. Ecology, 92, 9, $1839-1848$.

Boyero L., Pearson R.G., Dudgeon D., Ferreira V., Graça M.A.S., Gessner M.O., Boulton A.J., Chauvet E., Yule C.M., Albariño R.J., Ramírez A., Helson J.E., Callisto M., Arunachalam M., Chará J., Figueroa R., Mathooko J.M., Gonçalves J.F. Jr., Moretti M.S., Chará-Serna A.M., Davies J.N., Encalada A.C., Lamothe S., Buria L.M., Castela J., Cornejo A., Li A.O.Y., M'Erimba C., Villanueva V.D., Zúñiga M.C., Swan C.M. and Barmuta L.A., 2011b. Global patterns of stream detritivore distribution: implications for biodiversity loss in changing climates. Global Ecol. Biogeogr., 21, 134-141.

Boyero L., Pearson R.G., Gessner M.O., Barmuta L.A., Ferreira V., Graça M.A.S., Dudgeon D., Boulton A.J., Callisto M., Chauvet E., Helson J.E., Bruder A., Albariño R.J., Yule C.M., Arunachalam M., Davies J.N., Figueroa R., Flecker A.S., Ramírez A., Death R.G., Iwata T., Mathooko J.M., Mathuriau C., Gonçalves J.F. Jr., Moretti M.S., Jinggut T., Lamothe S., M'Erimba C., Ratnarajah L., Schindler M.H., Castela J., Buria L.M., Cornejo A., Villanueva V.D. and West D.C., 2011c. A global experiment suggests climate warming will not accelerate litter decomposition in streams but might reduce carbon sequestration. Ecol. Lett., 14, 289-294.

Camacho R., Boyero L., Cornejo A., Ibáñez A. and Pearson R.G., 2009. Local variation in shredder numbers can explain their oversight in tropical streams. Biotropica, 41, 625-632.

Chará J.D., Baird D., Telfer T. and Giraldo L.P., 2007. A comparative study of leaf breakdown of three native tree species in a slowly-flowing headwater stream in the Colombian Andes. Int. Rev. Hydrobiol., 92, 183-198.

Cheshire K., Boyero L. and Pearson R.G., 2005. Food webs in tropical Australian streams: shredders are not scarce. Freshwater Biol., 50, 748-769.

Chung N. and Suberkropp K., 2009. Contribution of fungal biomass to the growth of the shredder, Pycnopsyche gentilis (Trichoptera: Limniphilidae). Freshwater Biol., 54, 2212-2229.
Cummins K.W., 1974. Structure and function of stream ecosystems. BioScience, 24, 631-641.

Dobson M., Magana A., Mathooko J.M. and Ndegwa F.K., 2002. Detritivores in Kenyan highland streams: more evidence for the paucity of shredders in the tropics? Freshwater Biol., 47, 909-919.

Gonçalves J.F. Jr., Graça M.A.S. and Callisto M., 2007. Litter decomposition in a Cerrado savannah stream is retarded by leaf toughness, low dissolved nutrients and a low density of shredders. Freshwater Biol., 52, 1440-1451.

Heard S.B. and Richardson J.S., 1995. Shredder-collector facilitation in stream detrital food webs: is there enough evidence. Oikos, 72, 359-366.

Mantel S.K., Salas M. and Dudgeon D., 2004. Foodweb structure in a tropical Asian forest stream. J. North Am. Benth. Soc., 23, 728-755.

Merritt R.W. and Cummins K.W., 1996. An Introduction to the Aquatic Insects of North America, Kendall-Hunt Publishing Company, Dubuque, $862 \mathrm{p}$.

Motta R.L. and Uieda V.S., 2004. Diet and trophic groups of an aquatic insect community in a tropical stream. Braz. J. Biol., 64, 809-817.

Palmer C., O'Keeffe J., Palmer A., Dunne T. and Radloff S., 1993. Macroinvertebrate functional feeding groups in the middle and lower reaches of the Buffalo River, Eastern Cape, South Africa. I. Dietary variability. Freshwater Biol., 29, 441-453.

Ríos-Touma B., Encalada A. and Prat-Fornells N., 2009. Leaf litter dynamics and its use by invertebrates in a highaltitude tropical Andean stream. Int. Rev. Hydrobiol., 94, 357-371.

Rueda-Delgado G., Wantzen K.W. and Tolosa M.B., 2006. Leaf-Litter decomposition in an Amazonian floodplain stream: effects of seasonal hydrological changes. J. North Am. Benth. Soc., 25, 233-249.

Tomanova S., Goitia E. and Helešic J., 2006. Trophic levels and functional feeding groups of macroinvertebrates in neotropical streams. Hydrobiologia, 556, 251-264.

Wallace J.B., Eggert S.L., Meyer J.L. and Webster J.R., 1997. Multiple trophic levels of a forest stream linked to terrestrial litter inputs. Science, 277, 102-104.

Wantzen K.M. and Wagner R., 2006. Detritus processing by invertebrate shredders: a neotropical-temperate comparison. J. North Am. Benth. Soc., 25, 216-232.

Webster J.R. and Benfield E.F., 1986. Vascular plant breakdown in freshwater ecosystems. Annu. Rev. Ecol. Syst., 17, 567-594.

Wright M.S. and Covich A.P., 2005. The effect of macroinvertebrate exclusion on leaf breakdown rates in a tropical headwater stream. Biotropica, 37, 403-408.

Yule C.M., Boyero L. and Marchant R., 2010. Effects of sediment pollution on food webs in a tropical river (Borneo, Indonesia). Mar. Freshwater Res., 61, 204-213.

Yule C.M., Leong M.Y., Liew K.C., Ratnarajah L., Schmidt K., Wong H.M., Pearson R.G. and Boyero L., 2009. Shredders in Malaysia: abundance and species richness are higher in highland, temperate-like, tropical streams. J. North Am. Benth. Soc., 28, 404-415. 